
\title{
Neem underscores need for U.S. biodiversity role
}

By tapping into yet another dispute over biotechnology patenting, Rifkin has given the issue new legs and rounded up ready-made support groups on the subcontinent, in Europe and in the

There is very little these days that more sharply divides otherwise progressive-minded people, whatever their political persuasion, than the debate over the proper use of advanced technologies. This is especially true of the boom in advanced computer technology, which has spawned such works as Kirkpatrick Sale's Rebels Against the Future (Addison/Wesley, 1995), a meticulous study of the Luddite uprising in early 19 th century Midlands England. Indeed, Sale tried to kick off a revival of late 20 th-century neo-Luddism by gleefully smashing a computer with a sledgehammer during a symposium of "visionaries" in New York City last fall. Sale's counterpart in the arena of biotechnology, of course, is Jeremy Rifkin.

Rifkin, who heads the Foundation on Economic Trends (Washington, D.C.), would be the first to admit that he would like nothing more than to give the biotechnology industry the sledgehammer treatment. Indeed, Rifkin's recent legal challenge to W.R. Grace's (Boca Raton, FL) application to patent its process for extracting azadirachtin, a pesticidal product of the India neem tree, is the second blow Rifkin has struck this year at the patent process.

On the merits, Rifkin's latest foray into the propriety of patenting biotechnological processes, such as the extraction of pesticidal agents from the neem plant, is thin stuff. For starters, it has virtually nothing to do with Rifkin's campaign last summer for a moratorium on patenting living organisms, including "human embryos, genes, cells, and animals. ...." subject to manipulation by advanced genetic technologies-except by association. Although Rifkin and his followers will no doubt play fast and loose on the "colonialist" uses of Grace's se-cret industrial process and the awarding of a patent, this is hardly the patenting of living things. Rifkin is all-too-characteristically blowing smoke.

Moreover, the Indian government is not without blame. It has played a key role in fanning the flames of the neem controversy in order to stave off price increases associated with commercialization of natural uses of the plant. And yet it has quietly protected other substances extracted from the remarkable neem tree, including the natural spermicide DK- 1 , the technology for which India's Central Drug Research Institute (Lucknow) has reportedly transferred to two India drug companies for commercial development.

What's more, Grace has developed and used the pesticide extraction process at issue in its Bangalore (India) facilities for virtually exclusive use by Indian farmers. To seriously characterize the granting of a U.S. patent related to the neem tree, which can be and is grown in other parts of the world, as the corporate American plunder of an ageless Indian natural resource is at best hypocritical and at worst venal.

Like the religious movement against patenting living organisms that Rifkin exploited for his campaign last summer, the neem tree controversy has simmered for several years. By tapping into yet another dispute over biotechnology patenting, Rifkin has given the issue new legs and rounded up ready-made support groups on the subcontinent, in Europe and in the U.S.

This is smart strategic generalship, but all of Rifkin's maneuvers cannot hide the fact that, at bottom, the neem controversy is about a battle for control of a valuable natural resource. The biotechnology industry has become a pawn in what amounts to an old-fashioned trade war over the neem tree. If W.R. Grace is guilty of corporate colonialism or genetic imperialism, the New Delhi government is every bit as guilty of environmental protectionism. It is a fight that is destined to be fought out with the crude weapons available to both sides.

The real issue, of course, is whether international legal or diplomatic protocols can be developed that will establish internationally acceptable standards for patenting products developed from natural resources by advanced technological means. So far, the signs are not encouraging, either for industrial companies, which have the wherewithal to develop sophisticated and useful products, or for developing countries like India, which ultimately will benefit from them. Indian opponents of Grace, such as conservationist Vandana Shiva, the director of the Research Foundation for Science, Technology, and Natural Resources (Dehra Dun, India), have worked actively against efforts made in the Uruguay round of the General Agreement on Tariffs and Trade to align international patent law with existing law in the West.

Still, Rifkin once more has found the crack in the biotechnology industry's armor when its come to access to the world's biodiversity. Despite the best efforts of the industry and the Clinton administration, the U.S. has refused to be a party to the biodiversity treaty, an accord signed by most countries at the Rio conference on the environment in 1992. American participation in the treaty would have assured a U.S. seat at the table for ongoing debates about "adequate and effective" intellectual property protection, technology and benefit sharing, and standards for the commercialization and marketing of new technologies. Instead, Congress refused to sign, sending a message to the developing world that the U.S. was indifferent to their concerns.In many respects, W.R. Grace is now reaping what Congress has sown.

The neem controversy, and the possibility that in the future U.S. companies will be cut off from other biological resources, or face trade sanctions for violating the perceived interests of poorer countries, is an early warning to the biotechnology industry that its long-term interests are at risk. One way to beat Jeremy Rifkin at his own game is to mount a noisy campaign to get the U.S. back aboard the biodiversity treaty. III 